\title{
OCHRONA GATUNKOWA GRZYBÓW W PRAWIE POLSKIM
}

\section{SPECIES PROTECTION OF FUNGI IN THE POLISH LAW}

\section{STRESZCZENIE}

Grzyby są częścią dziedzictwa przyrodniczego kraju i podobnie jak inne organizmy wymagają ochrony. Polska stosunkowo wcześnie wprowadziła prawne regulacje dotyczące ochrony gatunkowej grzybów. Listy gatunków zawarte w kolejnych rozporządzeniach ulegały wielu modyfikacjom. Obecnie prawodawca postanowił objąć ochroną 322 gatunki grzybów wielkoowocnikowych i zlichenizowanych. Wprowadzono w stosunku do nich zróżnicowane rygory ochrony, wyróżniając ochronę ścisłą, częściową, częściową z możliwością pozyskiwania oraz strefową. Charakteryzuje je odmienny katalog zakazów

" Magister ochrony środowiska, student na kierunku prawo na Wydziale Prawa i Administracji UMK w Toruniu. 
i odstępstw od nich, które stanowią podstawowe narzędzie w trosce o zachowanie zagrożonych wyginięciem gatunków.

\section{Słowa kluczowe} biologiczna.

Grzyby; ochrona gatunkowa; ochrona przyrody; różnorodność

\section{ABSTRACT}

Fungi are part of the country's natural heritage and just like other organisms need protection. Poland has introduced quite early legal regulations concerning the species protection of fungi. The list of species, contained in the successive regulations, underwent many modifications. Currently, the legislator decided to extend the protection to 322 species of macrofungi and lichen. Differentiated protection categories have been introduced, such as strict protection, partial, partial with the possibility of acquiring and zonal. They are characterized by a different directory of prohibitions and exemptions from them, which is the main tool to save endangered species.

\section{Keywords}

Fungi; species protection; nature conservation; biodiversity.

\section{UWAGI WSTĘPNE}

Ochrona gatunkowa stanowi jedną z najstarszych form ochrony przyrody ${ }^{1}$. Pierwsze jej przejawy na ziemiach polski miały miejsce już w XI wieku, gdy Bolesław Chrobry wprowadził ochronę bobra ${ }^{2}$. Listy gatunków wydłużały się za panowania kolejnych władców, czego przykład stanowią: Statut Wiślicki, Warcki czy Statuty Litewskie Zygmunta I. W okresie zaborów,

1 W. Radecki, Zarys historii prawnej ochrony przyrody w Polsce, w: Prawne formy ochrony przyrody, red. J. Sommer, Warszawa 1990, s. 9.

2 R. Kapuściński, Historia ochrony przyrody $w$ Polsce (1). Ochrona przyrody $w$ Polsce do 1918 roku, „Przyroda Polska” 2013, nr 8, s. 4. 
mimo niesprzyjających okoliczności, podjęto udaną akcję ratowania zwierząt tatrzańskich - kozic i świstaków. Pierwszym aktem prawnym, który wprowadzał de facto ochronę gatunkową było Rozporządzenie Ministerstwa Wyznań Religijnych i Oświecenia Publicznego z dnia 15 września 1919 r. o ochronie niektórych zabytków przyrody ${ }^{3}$. Zabytki przyrody - relikty będące pozostałością po dawnych epokach, były formą ochrony, która dała początek współczesnej ochronie gatunkowej4 ${ }^{4}$ Systematyczne regulacje prawne zaczęły ukazywać się po II wojnie światowej w kolejnych ustawach o ochronie przyrody i aktach wykonawczych ${ }^{5}$.

Według art. 46 ust. 1 obowiązującej Ustawy $\mathrm{z}$ dnia 16 kwietnia 2004 r. o ochronie przyrody ${ }^{6}$ „ochrona gatunkowa obejmuje okazy gatunków oraz siedliska i ostoje roślin, zwierząt i grzybów". Tych ostatnich dotyczy Rozporządzenie Ministra Środowiska z dnia 9 października 2014 r. w sprawie ochrony gatunkowej grzybów ${ }^{7}$ wydane na podstawie art. 50 u.o.p. Zgodnie z tym przepisem kompetencje do jego wydania przyznano ministrowi właściwemu do spraw środowiska, który działa $\mathrm{w}$ porozumieniu $\mathrm{z}$ ministrem właściwym do spraw rolnictwa ${ }^{8}$. Ponadto wskazano czynniki, jakie powinny być uwzględnione przy jego wydawaniu. Są nimi: potrzeba ochrony dziko występujących grzybów, ich siedlisk, ostoi lub stanowisk oraz wymagania: ekologiczne, naukowe i kulturowe, a także obowiązujące w tym zakresie przepisy prawa unijnego. Rozporządzenie to będzie poddane szczegółowej analizie w niniejszym artykule, m.in. $\mathrm{z}$ powodu znacznych zmian $\mathrm{w}$ katalogu gatunków chronionych i wynikających $\mathrm{z}$ tego kontrowersji. Uwagi te poprze-

3 M. P. z 1919 r., nr 208.

4 U. Szymańska, w: U. Szymańska, E. Zębek, Prawo i ochrona środowiska, Olsztyn 2010, s. 195.

5 W. Radecki, Ustawa o ochronie przyrody. Komentarz, Warszawa 2012, s. 255.

6 T.j. Dz.U. z 2015 r., poz. 1651 ze zm., dalej cyt.: u.o.p.

7 Dz.U. z 2014 r., poz. 1408, dalej cyt.: RozpGrzyby.

8 B. Wierzbowski, B. Rakoczy, Prawo ochrony środowiska. Zagadnienia podstawowe, Warszawa 2012, s. 260-261. 
dzone zostaną krótką charakterystyką dotychczasowych rozporządzeń odnoszących się do prawnej ochrony grzybów.

Celem ochrony gatunkowej grzybów, jak również roślin i zwierząt jest - zgodnie z art. 46 ust. 2 u.o.p. - zapewnienie przetrwania i właściwego stanu ochrony dziko występujących gatunków rzadkich, endemicznych, podatnych na zagrożenia, zagrożonych wyginięciem i objętych ochroną na mocy umów międzynarodowych, a także ich siedlisk i ostoi oraz zachowanie różnorodności biologicznej. Wśród wspomnianych umów międzynarodowych powinny być uwzględnione zarówno te zawierane przez Unię Europejską, jak i podpisane bezpośrednio przez Polskę. Przykładowo należy wymienić tu Konwencję z dnia 5 czerwca 1992 r. o różnorodności biologicznej ${ }^{9}$ czy Konwencję z dnia 3 marca 1973 r. o międzynarodowym handlu dzikimi zwierzętami i roślinami gatunków zagrożonych wyginięciem ${ }^{10}$, a także, należącą do prawa pochodnego Unii Europejskiej, Dyrektywę Rady 92/43/EWG z dnia 21 maja 1992 r. w sprawie ochrony siedlisk naturalnych oraz dzikiej fauny i flory ${ }^{11}$. Cele powyższe nie mogą być realizowane bez odpowiednich rozporządzeń, w których wskazane zostały gatunki objęte ochroną i sposoby ich ochrony oraz zakazy, a także odstępstwa od nich.

Oprócz ochrony krajowej, ustanawianej przez ministra właściwego do spraw środowiska $\mathrm{w}$ odpowiednich rozporządzeniach, w art. 53 u.o.p. przewidziano możliwość wprowadzenia ochrony regionalnej. Kompetencję taką przyznano regionalnemu dyrektorowi ochrony środowiska, który na terenie województwa na czas określony $\mathrm{w}$ formie zarządzenia może ustanowić ochronę gatunków nieobjętych regulacjami ogólnokrajowymi.

9 Dz.U. z 2002 r., nr 184, poz. 1532.

10 Dz.U. z 1991 r., nr 27, poz. 112.

11 Dz. Urz. UE L 206 z 22.7.1992, s. 7, dalej cyt.: Dyrektywa 92/43/EWG. 


\section{PRZEDMIOT OCHRONY}

Ochrona gatunkowa grzybów, jak łatwo się domyślić, zmierza do ochrony gatunków grzybów. Jak stanowi art. 5 pkt 1 u.o.p., pod pojęciem gatunku rozumie się „zarówno gatunek w znaczeniu biologicznym, jak i każdą niższą od gatunku biologicznego jednostkę systematyczną, populację, a także mieszańce tego gatunku $\mathrm{w}$ pierwszym lub drugim pokoleniu, z wyjątkiem form, ras i odmian udomowionych, hodowlanych lub uprawnych". Zakresem ochrony objęte są: okazy gatunków grzybów, ich siedliska oraz ostoje. Za okaz gatunku ustawodawca każe przyjąć grzyb z danego gatunku, każdą jego część, formę rozwojową, a także jego produkty pochodne oraz towary, które zawierają części grzyba lub jego produkty pochodne (art. 5 pkt 11a u.o.p.). Siedlisko grzybów to obszar występowania grzybów w ciągu całego życia lub dowolnym stadium ich rozwoju (art. 5 pkt 18 u.o.p.). Z kolei ostoją jest miejsce o warunkach sprzyjających egzystencji gatunków grzybów zagrożonych wyginięciem lub rzadkich (art. 5 pkt 12 u.o.p.).

Dotąd w Polsce stwierdzono występowanie około 4250 grzybów wielkoowocnikowych oraz około 1520 grzybów zlichenizowanych ${ }^{12}$. Podział taki (sztuczny, nie znajdujący odzwierciedlenia $\mathrm{w}$ systematyce organizmów żywych) przyjął prawodawca w RozpGrzyby, wyróżniając dwie gromady: grzyby wielkoowocnikowe ${ }^{13}$ i zlichenizowane ${ }^{14}$ (porosty). Wśród tej

12 Aktualizacja listy gatunków grzybów objętych ochrona gatunkową oraz wskazania dla ich ochrony, red. A. Kepel, Poznań 2013, s. 5.

13 Sztuczna grupa grzybów obejmująca gatunki o owocnikach widocznych gołym okiem: najczęściej przyjmuje się, że ich wielkość wynosi co najmniej 2 lub $5 \mathrm{~mm}$.

14 Porosty (Lichenes/Fungi lichenisati) - są to tzw. grzyby zlichenizowane, wyróżniające się specyficzną strategią odżywczą. Polega ona na pobieraniu produktów asymilacji glonów, z którymi grzyb żyje w symbiozie. Jest to powszechne zjawisko wśród przedstawicieli grzybów, występuje u ponad 20\% gatunków. Porost jest związkiem między grzybem i jednym bądź wieloma samożywnymi partnerami, którymi mogą być glony eukariotyczne - zielenice bądź prokariotyczne - sinice. 
bardzo zróżnicowanej grupy organizmów występują zarówno gatunki pospolite, ekspansywne, jak i rzadkie, ustępujące i zagrożone wyginięciem. Do głównych czynników zagrażających grzybom należą zanikanie, a także niszczenie siedlisk, zanieczyszczenie wody, powietrza i gleby oraz nadmierny zbiór owocników. Informacji o stopniu zagrożenia poszczególnych gatunków dostarczają tzw. czerwone listy i księgi gatunków zagrożonych. Listy takie nie stanowią podstawy prawnej ochrony organizmów, ale są cenną inspiracją do weryfikacji gatunków objętych ochroną gatunkową. Czerwona lista grzybów wielkoowocnikowych zawiera wykaz gatunków uznanych za zagrożone oraz ocenę tego zagrożenia ${ }^{15}$. Pierwsza taka czerwona lista powstała w 1986 r. i obejmowała 800 gatunków. Na czerwonej liście z 2006 r. umieszczono 963 gatunki grzybów, w tym za najbardziej zagrożone uznano 423. Jednakże nie wszystkie dane o gatunkach w tym opracowaniu są aktualne, wielu gatunków skrajnie rzadkich i zagrożonych brakuje na niej, a dla wielu, po ponownym rozpatrzeniu ich zagrożenia, kategoria zagrożenia ulegnie zapewne zmianie. Niemniej jednak kategorie zagrożenia Międzynarodowej Unii Ochrony Przyrody (ang. International Union for Conservation of Nature - IUCN) według aktualnych czerwonych list i ksiąg gatunków zagrożonych stanowiły podstawowe kryterium przy wyborze gatunków do objęcia ochroną na mocy RozpGrzyby ${ }^{16}$.

Zróżnicowany status gatunków, przejawiający się w stopniu ich zagrożenia i wrażliwości na zmiany w środowisku, wymusza przyjęcie podziału na ochronę ścisłą i częściową ${ }^{17}$. Jak stanowi art. 5 pkt 9 u.o.p., ochrona ścisła w przypadku gatunków oznacza całoroczną ochronę należących do nich osobników

15 A. Kujawa, Ochrona grzybów wielkoowocnikowych $w$ Polsce - stan aktualny, problemy $i$ wyzwania. Głos $w$ dyskusji, „Przegląd Przyrodniczy” 2010, nr 2, s. 43.

16 Uzasadnienie do Projektu rozporządzenia Ministra Środowiska z dnia 3 października 2014 r. w sprawie ochrony gatunkowej grzybów, s. 1, http:// legislacja.rcl.gov.pl/docs//515/224497/224537/dokument131424.pdf [dostęp: 19.05.2015 r.]

17 A. Jaworowicz-Rudolf, w: Prawo ochrony środowiska, red. M. Górski, Warszawa 2014, s. 551. 
i stadiów ich rozwoju. Natomiast pkt 4 powyższego artykułu ochronę częściową definiuje jako ochronę gatunków dopuszczającą możliwość redukcji liczebności populacji oraz pozyskiwania osobników tych gatunków lub ich części.

Co do zasady ochrona gatunkowa ma charakter ochrony in situ ${ }^{18}$. Oznacza ona ochronę gatunków w miejscach ich naturalnego występowania. Innym, uzupełniającym sposobem jest ochrona ex situ, czyli poza obszarem naturalnego występowania gatunków. Działania w jej ramach mogą być realizowane m.in. w ogrodach botanicznych i bankach genów. Niestety w przypadku grzybów takie poczynania napotykają poważne trudności. Dotyczy to zwłaszcza tzw. grzybów mikoryzowych, które tworzą złożone i skomplikowane związki z roślinami. Dlatego tak ważne w ochronie grzybów jest zachowanie ich siedlisk, miejsc i podłoży, w których żyją. Dla pełnego utrzymania bogactwa gatunkowego, ochrona gatunkowa musi być uzupełniana o różne formy obszarów chronionych - głównie w ramach parku narodowego lub rezerwatu przyrody.

\section{STAN PRAWNY DO 16 PAŹDZIERNIKA 2014 R.}

Pierwsze postulaty ochrony grzybów zlichenizowanych pojawiły się już podczas prac nad Ustawą z dnia 10 marca 1934 r. o ochronie przyrody ${ }^{19}$, nie zostały one jednak uwzględnione ${ }^{20}$.

Na mocy Ustawy z dnia 7 kwietnia 1949 r. o ochronie przyrody $^{21}$ wprowadzono Rozporządzenie Ministra Leśnictwa i Przemysłu Drzewnego z dnia 28 lutego 1957 r. w sprawie wprowadzenia gatunkowej ochrony roślin ${ }^{22}$. Mimo iż dotyczyło ono roślin, to po raz pierwszy objęto ochroną specyficzną

18 A. Jaworowicz-Rudolf, w: Prawo ochrony różnorodności biologicznej, red. M. Górski, J. Miłkowska-Rębowska, Warszawa 2013, s. 92.

19 Dz.U. z 1934, nr 31, poz. 274 ze zm.

20 M. Latawiec, Analiza historyczna ustawowych form ochrony przyrody $w$ Polsce, Warszawa 2011, s. 118-119.

21 Dz.U. z 1949, nr 25, poz. 180 ze zm.

22 Dz.U. z 1957, nr 15, poz. 78. 
grupę grzybów - porosty (Lichenes). Za podlegające ochronie częściowej uznano w $\S 5$ pkt 1 tego rozporządzenia: płucnicę islandzką, granicznika płucnika oraz wszystkie gatunki z rodzaju brodaczka. Zostały one wskazane jako gatunki roślin leczniczych i przemysłowych dziko rosnących ${ }^{23}$. Zbiór porostów nadrzewnych dopuszczalny był $\mathrm{z}$ drzew ściętych w normalnym trybie gospodarki leśnej.

Kolejny akt wykonawczy, tj. Rozporządzenie Ministra Leśnictwa i Przemysłu Drzewnego z dnia 30 kwietnia 1983 r. w sprawie wprowadzenia gatunkowej ochrony roślin ${ }^{24}$, nie dokonał żadnych zmian wobec ochrony porostów. Jednakże po raz pierwszy wprowadzono ochronę całkowitą grzybów, do których należały: wszystkie gatunki smardzowatych i sromotnikowatych, a ponadto: szmaciak gałęzisty, soplówka gałęzista i jodłowa, modrzewnik lekarski, flagowiec olbrzymi, żagwica listkowata i okółkowa, szyszkowiec szyszkowaty, podgrzybek pasożytniczy oraz purchawica olbrzymia. Liczba gatunków chronionych wynosiła $20^{25}$. Podkreślenia wymaga treść $\S 2$ ust. 1 pkt 2 owego rozporządzenia, który ustanawiał zakaz „niszczenia owocników wszelkich gatunków grzybów nie zbieranych w celach konsumpcyjnych na ich naturalnych stanowiskach w lasach, na łąkach, w murawach, zaroślach itp.". Można w brzmieniu tegoż przepisu odnaleźć przejawy koncepcji tzw. powszechnej ochrony przyrody. Uregulowanie to z całą pewnością stanowi innowatorskie podejście w gatunkowej ochronie grzybów ${ }^{26}$.

Na podstawie nowej już ustawy o ochronie przyrody, tj. Ustawy z dnia 16 października 1991 r. o ochronie przyro$\mathrm{dy}^{27}$, wprowadzono Rozporządzenie Ministra Ochrony Środo-

23 W starszych systematykach porosty zaliczane były do roślin i wyróżniane $\mathrm{w}$ randze gromady. Taksonomia tych organizmów pod koniec XX wieku przeszła szereg fundamentalnych zmian. W rezultacie porosty klasyfikowane są jako grzyby.

24 Dz.U. z 1983, nr 27, poz. 134.

25 W literaturze spotkać się można także z liczbą 21 gatunków, co bierze się z objęcia ochroną nieraz całych rodzin, których liczba gatunków nie jest jednoznaczna.

27 Dz.U. z 1991, nr 114, poz. 492 ze zm. 
wiska, Zasobów Naturalnych i Leśnictwa z dnia 6 kwietnia 1995 r. w sprawie ochrony gatunkowej roślin ${ }^{28}$. Po raz pierwszy ochronie ścisłej (dotychczasowa ochrona całkowita) poddano porosty w liczbie 218 gatunków. Były to m. in. wszystkie gatunki z rodziny brodaczkowatych, granicznikowatych, pawężnicowatych i tarcznicowatych (z nielicznymi wyjątkami) oraz z rodzaju obrostnica, chruścik i chrobotek. Ochronie częściowej podlegała tylko płucnica islandzka. W stosunku do pozostałych grzybów rozszerzono ochronę ścisłą na wszystkie gatunki z rodzaju szmaciak i soplówka. Łącznie ochroną ścisłą objęto 23 gatunki grzybów. Rozporządzenie wprowadzało również ochronę częściową w stosunku do tych grzybów, które nie zostały objęte reżimem ochrony ścisłej. Zabieg ten stanowił znaczący postęp w ochronie grzybów w stosunku do poprzedniego stanu prawnego.

Kolejnym aktem było Rozporządzenie Ministra Środowiska z dnia 11 września 2001 r. w sprawie listy gatunków roślin rodzimych dziko występujących, objętych ochroną gatunkową ścisłą, częściową oraz zakazów właściwych dla tych gatunków i odstępstw od tych zakazów ${ }^{29}$. Nowym rozwiązaniem było umieszczenie gatunków w załącznikach do rozporządzenia. Pierwszy z nich określał gatunki poddane ochronie ścisłej. Były to 23 gatunki grzybów, które były chronione również na mocy uprzedniego rozporządzenia. Pozostałe gatunki objęto ochroną częściową. Ich wykaz zawierał załącznik drugi. Natomiast w stosunku do porostów rozszerzono jedynie ochronę ścisłą na kolejne dwa gatunki z rodziny pawężnicowatych.

Aktualnie obowiązujące RozpGrzyby było poprzedzone Rozporządzeniem Ministra Środowiska z dnia 9 września 2004 r. w sprawie gatunków dziko występujących grzybów objętych ochroną ${ }^{30}$. Wydane ono zostało już w oparciu o przepisy obowiązującej u.o.p. W art. 46 ust. 1 tej ustawy po raz pierwszy zdecydowano się na wyodrębnienie ochrony gatunkowej grzy-

Dz.U. z 2001, nr 106, poz. 1167.

30 Dz.U. z 2004, nr 168, poz. 1765. 
bów z dotychczasowego łączenia ich z ochroną roślin ${ }^{31}$. Rozporządzenie zawierało cztery załączniki z wykazami gatunków dziko występujących grzybów. Pierwszy z nich wskazywał gatunki objęte ochroną ścisłą. Takiej ochronie poddano 95 gatunków grzybów i 242 gatunki porostów. Drugi załącznik określał gatunki objęte ochroną częściową. Na liście znalazł się włóknouszek ukośny oraz 9 gatunków porostów. W porównaniu do poprzedniego rozporządzenia liczba gatunków grzybów objętych ochroną częściową uległa drastycznemu ograniczeniu. Wcześniej były nią objęte prawie wszystkie grzyby, z wyłączeniem gatunków ściśle chronionych. W trzecim załączniku wskazano po jednym gatunku z gromady grzybów i porostów objętych ochroną częściową, które mogą być pozyskiwane oraz sposoby ich pozyskiwania. Były to odpowiednio włóknouszek ukośny i płucnica islandzka. Dopuszczalnym sposobem ich pozyskiwania był zbiór ręczny. Natomiast czwarty załącznik określał gatunki wymagające ustalenia stref ochrony ich ostoi lub stanowisk. Gatunki te podlegały jednocześnie ochronie ścisłej. W poprzednich aktach wykonawczych dotyczących grzybów strefy ochronne nie były stosowane. Temu reżimowi zostały poddane wyłącznie porosty, do których należały takie gatunki, jak: granicznik płucnik, brodaczka kędzierzawa, kępkowa i zwyczajna. Wielkość strefy w stosunku do pierwszego z wymienionych taksonów wynosiła 100 m od granic stanowiska, zaś w stosunku do pozostałych 50 m. Wybór gatunków objętych tego rodzaju ochroną wzbudzał wiele kontrowersji ${ }^{32}$. Zdaniem Państwowej Rady Ochrony Przyrody lista ta stanowiła wynik błędu ministra ${ }^{33}$.

31 M. Latawiec, op. cit., s. 121.

32 E. Symonides, Ochrona przyrody, Warszawa 2007, s. 576.

33 Państwowa Rada Ochrony Przyrody, Najważniejsze problemy ochrony przyrody $w$ Polsce, Warszawa 2007, s. 14, www.prop.org.pl/index.php 


\section{STAN PRAWNY PO DNIU 16 PAŹDZIERNIKA 2014 R.}

RozpGrzyby zastąpiło poprzednie rozporządzenie w związku ze zmianami wprowadzonymi Ustawą z dnia 13 lipca 2012 r. o zmianie Ustawy o ochronie przyrody oraz niektórych innych ustaw $^{34}$. Nowelizacja ta dokonała zmiany m. in. art. 50 i 51 u.o.p., określających wytyczne do wydania analizowanego rozporządzenia oraz jego zakresu. Wśród powodów zmiany przepisów prawnych wskazuje się także na potrzebę aktualizacji gatunków chronionych i dostosowanie zakazów do potrzeb ich ochrony ${ }^{35}$.

RozpGrzyby wyróżnia gatunki grzybów objęte ochroną ścisłą; ochroną częściową; ochroną częściową, które mogą być pozyskiwane i sposoby ich pozyskiwania; a także gatunki wymagające ustalenia stref ochrony ich ostoi lub stanowisk. Gatunki należące do wskazanych kategorii ochrony umieszczono odpowiednio w załącznikach od 1 do 4 . Gatunki grzybów pogrupowano $\mathrm{w}$ wyższe jednostki systematyczne. W ramach gromady grzybów wielkoowocnikowych poszczególne gatunki zostały zestawione w rodziny. W przypadku grzybów zlichenizowanych nie wprowadzono nazw rodzin ze względu na częste zmiany w taksonomii. Nazwy gromad, rodzin oraz nazwy gatunkowe posiadają swoje odpowiedniki w „nazwie naukowej”. Ponadto rozporządzenie zawiera właściwe zakazy i odstępstwa od nich dla poszczególnych gatunków lub grup gatunków grzybów, a także sposoby ich ochrony.

Prawodawca uznał potrzebę prawnej ochrony 322 gatunków grzybów, z czego 205 to porosty, a 117 grzyby wielkoowocnikowe. W stosunku do poprzedniej regulacji (341 $31^{36}$ taksonów) liczba ta niewiele się zmieniła. Zaszły jednak dość istotne zmiany jakościowe. W RozpGrzyby znalazło się 259 gatunków wspólnych dla rozporządzeń z 2004 r. i 2014 r. Natomiast reszta, czyli 63 gatunki nie były we wcześniejszej regulacji ujęte.

34 Dz.U. z 2012, poz. 985, dalej cyt.: nowelizacja u.o.p.

35 Uzasadnienie do Projektu rozporządzenia Ministra Środowiska z dnia 3 października 2014 r. w sprawie ochrony gatunkowej grzybów, s. 1.

36 W zależności od źródła spotkać można się także z liczbą 347 gatunków. 
Przyczynami wprowadzenia nowych gatunków było dotychczasowe nieuwzględnienie wielu taksonów bardzo rzadkich, zagrożonych wyginięciem, znanych $\mathrm{z}$ pojedynczych stanowisk oraz znalezienie nowych gatunków dla Polski rzadkich w Europie i Polsce ${ }^{37}$.

W załączniku nr 1 zamieszczono gatunki objęte ochroną ścisłą. Do tej kategorii ochrony zakwalifikowano taksony grzybów zagrożonych w Polsce, posiadających najwyższe kategorie zagrożenia według IUCN (tj. EXP, EW, CR, EN) ${ }^{38}$. W wykazie zawarto 54 gatunki grzybów wielkoowocnikowych i 178 gatunków porostów. W stosunku do dziko występujących gatunków poddanych takiej ochronie prawodawca, na mocy § 6 ust. 1 RozpGrzyby, wprowadza następujące zakazy: „1) umyślnego niszczenia; 2) umyślnego zrywania lub uszkadzania; 3) niszczenia ich siedlisk; 4) pozyskiwania lub zbioru; 5) przetrzymywania lub posiadania okazów gatunków; 6) zbywania, oferowania do sprzedaży, wymiany lub darowizny okazów gatunków; 7) wwożenia z zagranicy lub wywożenia poza granicę państwa okazów gatunków; 8) umyślnego przemieszczania w środowisku przyrodniczym; 9) umyślnego wprowadzania do środowiska przyrodniczego".

Są to zakazy wybrane z zamkniętego katalogu zakazów $\mathrm{z}$ art. 51 u.o.p., który reguluje dopuszczalne zakazy w stosunku do dziko występujących roślin lub grzybów gatunków objętych ochroną gatunkową. Jak łatwo zauważyć, w analizowanym rozporządzeniu nie skorzystano z następujących zakazów: dokonywania zmian stosunków wodnych, stosowania środków chemicznych, niszczenia ściółki leśnej lub niszczenia gleby w ostojach, hodowli, transportu okazów gatunków, a także niszczenia ostoi. Brak wprowadzenia pierwszego z zaprezentowanych zakazów należy ocenić negatywnie. Przykładowo dla porostów naziemnych (epigeicznych) stan podłoża, tj. m. in. ilość składników mineralnych, wilgotność, stopień jego zanieczyszczenia, będzie

37 Uzasadnienie do Projektu rozporządzenia Ministra Środowiska z dnia 3 października 2014 r. w sprawie ochrony gatunkowej grzybów, s. 1.

38 Ibidem. 
odgrywał pierwszorzędne znaczenie ${ }^{39}$. Jakiekolwiek negatywne zjawiska w jego parametrach mogą skutkować ustępowaniem okazów gatunków. Realny stopień ochrony mógłby zapewnić jedynie wspomniany zakaz, który został niestety pominięty. Brak zakazu niszczenia ostoi uzasadniany jest obawą, że ochronie podlegałyby zbyt duże obszary, o nieokreślonych granicach, a nawet miejsca, które mogłyby być zasiedlone przez gatunki w przyszłości. Zastrzeżenia te wynikać mają z brzmienia ustawowej definicji ostoi. Stanowisko takie nie jest jednak uzasadnione, gdyż po pierwsze sam ustawodawca wprowadza taką możliwość, więc nie wydaje się, aby zakaz ten był nieracjonalny. Po drugie zaś, widoczne gołym okiem owocniki grzybów to tylko niewielka część organizmu, którego ochrona powinna rozciągać się na większy obszar niż tylko siedlisko.

Zmiana art. 51 ust. 1 u.o.p. dokonana nowelizacją u.o.p. spowodowała, że część zakazów odnosi się tylko do działań o charakterze umyślnym, a zatem takim, które z punktu widzenia odpowiedzialności karnej miałoby charakter zawiniony. „Wprowadzenie takiego rozwiązania, jest o tyle dziwne, że umyślność w działaniu nie jest niezbędna w przypadku innych naruszeń. Okoliczność ta może mieć szczególne znaczenie w przypadku dużych przedsięwzięć mogących wywrzeć znaczące oddziaływanie na chronione składniki środowiska przyrodniczego, które niekoniecznie wszystkie musiały być zinwentaryzowane na etapie przeprowadzania oceny oddziaływania na środowisko"40.

Paragraf 7 RozpGrzyby wprowadza trzy grupy odstępstw od zakazów. Odstępstwa te dotyczą zarówno dziko występujących grzybów objętych ochroną ścisłą, jak i częściową. Po pierwsze zakazy: umyślnego niszczenia, uszkadzania i niszczenia siedlisk nie dotyczą wykonywania czynności związanych z prowadzeniem racjonalnej gospodarki rolnej, leśnej lub rybackiej, pod warunkiem, że technologia prac uniemożliwia przestrzeganie tych zakazów. Odstępstwa te nie mają zastosowania do gatun-

39 Zob. np. W. Fałtynowicz, Zagrożenia porostów i problemy ich ochrony, „Przegląd Przyrodniczy” 1997, nr 3, s. 35-46.

40 K. Gruszecki, Ustawa o ochronie przyrody. Komentarz, Warszawa 2013, s. 305 . 
ków oznaczonych w załącznikach nr 1 i 2 symbolem (1). Jest to wynik rozwiązania przyjętego w art. 51 ust. 3 u.o.p., który nie zezwala na odstępstwa w stosunku do gatunków wymienionych w załączniku IV Dyrektywy 92/43/EWG. Nie wprowadzono odstępstwa dla gatunków znanych z pojedynczych stanowisk, jak również uznanych za wymarłe lub krytycznie zagrożone, a także rosnących na skałach, martwym drewnie, w borach bagiennych czy torfowiskach ${ }^{41}$. Odstępstwa nie dotyczą 81 gatunków grzybów znajdujących się pod ochroną ścisłą oraz 35 pod ochroną częściową. Po drugie zakazy: umyślnego niszczenia i uszkadzania nie dotyczą pozyskania okazów gatunków określonych w załączniku nr 3 przez podmioty, które uzyskały zezwolenie regionalnego dyrektora ochrony środowiska lub Generalnego Dyrektora Ochrony Środowiska na ich pozyskanie. Okazy pozyskane na podstawie takiego zezwolenia mogą podlegać przetrzymywaniu, posiadaniu, zbywaniu, oferowaniu do sprzedaży, wymianie, darowiznom i wywożeniu poza granicę państwa. Wreszcie, po trzecie, zakazy: umyślnego niszczenia, uszkadzania, przetrzymywania, posiadania, zbywania, oferowania do sprzedaży, wymiany, darowizny i wywożenia poza granicę państwa okazów gatunków nie dotyczą okazów gatunków pozyskanych poza granicą państwa i wwiezionych z zagranicy na podstawie zezwolenia regionalnego dyrektora ochrony środowiska lub Generalnego Dyrektora Ochrony Środowiska.

Zezwolenia na czynności podlegające zakazom lub ograniczeniom w stosunku do gatunków objętych zarówno ochroną ścisłą, jak i częściową wydawane są na wniosek, zgodnie z treścią art. 56 u.o.p. Zezwolenie przybiera formę decyzji administracyjnej. Powinno z niej wynikać kto, gdzie i kiedy może podejmować określone działania, jakiego gatunku dotyczy zezwolenie oraz wskazywać termin na złożenie informacji o jego wykorzystaniu ${ }^{42}$. Organy właściwe do wydania zezwoleń kontrolują spełnianie warunków określonych w zezwoleniach poprzez czynności kontrolne upoważnionych przez siebie osób. Zasadni-

41 Uzasadnienie do Projektu rozporządzenia Ministra Środowiska z dnia 3 października 2014 r. w sprawie ochrony gatunkowej grzybów, s. 12.

42 A. Jaworowicz-Rudolf, op. cit., s. 89. 
czo zezwolenia mogą być wydane w przypadku braku rozwiązań alternatywnych i jeżeli nie są szkodliwe dla zachowania we właściwym stanie ochrony dziko występujących populacji chronionych gatunków. Jest to tzw. przesłanka generalna. Ponadto niezbędne jest równoczesne wystąpienie jednej z indywidualnych przyczyn wymienionych $\mathrm{w}$ art. 56 ust. 4 u.o.p. Są nimi m. in.: ochrona dziko występujących gatunków roślin, zwierząt, grzybów lub siedlisk przyrodniczych, konieczność ograniczenia poważnych szkód, zdrowie lub bezpieczeństwo powszechne, realizacja badań naukowych. W przypadku gatunków objętych ochroną ścisłą oraz gatunków wymienionych w załączniku IV Dyrektywy 92/43/EWG indywidualną przesłankę na wydanie zezwolenia stanowić mogą konieczne wymogi nadrzędnego interesu publicznego, w przypadku zaś pozostałych gatunków słuszny interes strony lub konieczne wymogi nadrzędnego interesu publicznego. Natomiast w stosunku do grzybów gatunków poddanych ochronie częściowej, z możliwością pozyskiwania zastosowanie znajduje ust. 5 art. 56 u.o.p. Zezwolenie na pozyskiwanie takich gatunków może być wydane, jeżeli nie jest szkodliwe dla zachowania we właściwym stanie ochrony dziko występujących populacji chronionych gatunków roślin, zwierząt lub grzybów.

Ochronie częściowej zostały poddane 63 gatunki grzybów wielkoowocnikowych i 27 gatunków porostów, które zostały wymienione w załączniku nr 2 do RozpGrzyby. Dziko występujące gatunki z tego załącznika, jak stanowi $\S 6$ ust. 2 RozpGrzyby, podlegają zakazom: „1) umyślnego niszczenia; 2) umyślnego zrywania lub uszkadzania; 3) niszczenia ich siedlisk; 4) pozyskiwania lub zbioru; 5) umyślnego przemieszczania w środowisku przyrodniczym; 6) umyślnego wprowadzania do środowiska przyrodniczego".

Od powyższych zakazów dopuszczalne są odstępstwa, które reguluje omówiony już wyżej § 7 RozpGrzyby.

Novum normatywnym analizowanego rozporządzenia jest zróżnicowanie gatunków chronionych grzybów na gatunki dziko występujące i inne niż dziko występujące. Implikuje on zarazem odmienny katalog obowiązujących zakazów. Wyżej zaprezentowane zakazy i odstępstwa od nich dotyczą dziko występujących 
gatunków chronionych. Natomiast w stosunku do drugiej grupy gatunków ust. $3 \S 6$ RozpGrzyby ustanawia jedynie zakaz umyślnego wprowadzania do środowiska przyrodniczego.

Załącznik 3 do RozpGrzyby zawiera wykaz gatunków objętych ochroną częściową, które mogą być pozyskiwane oraz sposoby ich pozyskiwania. Znalazło się w nim 9 gatunków grzybów wielkoowocnikowych i 1 gatunek z gromady porostów (płucnica islandzka). W stosunku do poprzedniej regulacji lista gatunków grzybów wielkoowocnikowych uległa wydłużeniu. Dopuszczalnym sposobem pozyskiwania okazów jest zbiór ręczny owocników bądź plech. W przypadku jednego gatunku przewidziano możliwość odcięcia narośli na drzewie narzędziem o ostrej krawędzi.

W ostatnim z załączników prawodawca wskazuje gatunki wymagające ustalenia stref ochrony. Podobnie jak w poprzednim stanie prawnym, tak i na podstawie RozpGrzyby, w wykazie znalazły się wyłącznie porosty. Obecnie załącznik 4 wymienia 11 gatunków, natomiast rozporządzenie z 2004 r. przewidywało 4 gatunki. Jedynie granicznik płucnik w dalszym ciągu pozostaje pod ochroną strefową. Po raz pierwszy ochronie strefowej poddano następujące gatunki: granicznik tarczownicowy i tarczowy, kobiernik Arnolda, orzęsiony, postrzępiony i wybredny, mąkla rozłożysta, odnożyca włosowata, pawężniczka sorediowa oraz puchlinka ząbkowana. Większość z nich podawana jest $\mathrm{z}$ od jednego do kilkunastu znanych stanowisk w Polsce (często w parkach narodowych) ${ }^{43}$. Są one zarazem gatunkami parasolowymi ${ }^{44}$ dla innych grzybów zlichenizowanych oraz organizmów z innych grup. Strefa ochrony obejmuje stanowisko wraz $\mathrm{z}$ ostoją o promieniu do $50 \mathrm{~m}$ od stanowiska. Nie powstaje ona $\mathrm{z}$ mocy prawa, lecz w formie decyzji administracyjnej wydawanej przez regionalnego dyrektora ochrony środowiska ${ }^{45}$. Organ

43 Uzasadnienie do Projektu rozporządzenia Ministra Środowiska z dnia 3 października 2014 r. w sprawie ochrony gatunkowej grzybów, s. 10.

44 Są to gatunki stosunkowo łatwo rozpoznawalne, których ochrona automatycznie pociąga za sobą ochronę wielu innych, zazwyczaj mniej „charakterystycznych" zwierząt, roślin i grzybów.

45 K. Gruszecki, op. cit., s. 297. 
ten prowadzi także ich rejestr. Granice stref ochrony powinny być oznaczone odpowiednimi tablicami. W strefach ochrony w myśl art. 60 ust. 6 u.o.p. zabrania się: „1) przebywania osób, z wyjątkiem właściciela nieruchomości objętej strefą ochrony oraz osób sprawujących zarząd i nadzór nad obszarami objętymi strefą ochrony, oraz osób wykonujących prace na podstawie umowy zawartej z właścicielem lub zarządcą; 2) wycinania drzew lub krzewów; 3) dokonywania zmian stosunków wodnych, jeżeli nie jest to związane z potrzebą ochrony poszczególnych gatunków; 4) wznoszenia obiektów, urządzeń i instalacji”. Jak stanowi ust. 7 przywołanego powyżej artykułu, regionalny dyrektor ochrony środowiska może wydać zezwolenie na odstąpienie od powyższych zakazów, kierując się wymogami ochrony ostoi oraz stanowisk roślin, zwierząt lub grzybów objętych ochroną gatunkową.

W § 8 RozpGrzyby wskazano sposoby ochrony gatunków chronionych. Wyliczenie jest obszerne i składa się z 14 punktów. Zostały one wymienione wyczerpująco, inaczej niż w dotychczasowym porządku prawnym. Ochrona grzybów może polegać $\mathrm{m}$. in. na inwentaryzowaniu, monitorowaniu i zabezpieczaniu stanowisk, a przede wszystkim wykonywaniu zabiegów ochronnych. Zachowanie niektórych siedlisk (murawy kserotermiczne, suche wrzosowiska, bory chrobotkowe), z którymi związane są pewne gatunki chronione możliwe jest dzięki ochronie czynnej. Powyższe sposoby mają być realizowane przez organy administracji publicznej, osoby prawne i inne jednostki organizacyjne oraz osoby fizyczne, przy zapewnieniu warunków organizacyjnych i finansowych przez organy administracji publicznej, zgodnie $\mathrm{z}$ art. 4 ust. 1 i 2 u.o.p.

Przyjęcie nowego rozporządzenia dotyczącego ochrony grzybów wiązało się z silną krytyką środowisk eksperckich. Najsilniejszy sprzeciw wywołał Projekt Rozporządzenia Ministra Środowiska z dnia 9 czerwca 2014 r. w sprawie ochrony gatunkowej grzybów ${ }^{46}$. Określony został jako wypaczenie idei ochrony przyrody, zaś jego uzasadnienie zawierało dużo niespójności,

46 http://legislacja.rcl.gov.pl/docs//515/224497/224516/224517/dokument116011.pdf [dostęp: 19.05.2015 r.] 
uproszczeń i uogólnień wprowadzających w błąd oraz nieprawdziwych założeń i opinii ${ }^{47}$. Przewidywał ochronę zaledwie 201 gatunków, wybranych w oparciu o niezrozumiałe i nieznajdujące merytorycznego uzasadnienia kryteria. Do opracowania projektu rozporządzenia wykorzystano ekspertyzę pt. Aktualizacja listy gatunków grzybów objętych ochrona gatunkowa oraz wskazania dla ich ochrony, wykonaną przez Polskie Towarzystwo Ochrony Przyrody „Salamandra” na zlecenie Generalnej Dyrekcji Ochrony Środowiska. Co ciekawe jego współautorka nadużyciem nazywa cytowanie w uzasadnieniu projektu powyższego opracowania jako źródła, na którym się oparto. Ogromne zaniepokojenie wyrażał także Zarząd Polskiego Towarzystwa Mykologicznego. Stwierdził on, że projekt ten jest nie do przyjęcia z wielu powodów, nie zapewnia także osiągnięcia celów ochrony przyrody określonych w art. 2 ust. 2 u.o.p. i nie wypełnia obowiązku określonego w art. 4 ust. 2 tejże ustawy.

Przytoczone wyżej przykłady są tylko jednymi z licznych głosów w trakcie procedury konsultacji społecznych nad projektem nowego rozporządzenia. Tak jednoznaczne, krytyczne stanowisko ekspertów świadczy o niepokojącym zjawisku w procesie legislacji. Niedopuszczalne jest ignorowanie naukowych argumentów w kwestiach wymagających ściśle wyspecjalizowanej wiedzy. Do takich należy przede wszystkim ustalenie list gatunków wymagających prawnie zagwarantowanej ochrony ze strony państwa. Zrozumiała jest konieczność ważenia interesów gospodarczych, społecznych i środowiskowych. Nie może ono jednak skutkować de facto pozbawieniem ochrony całej grupy organizmów, którą gwarantuje ustawodawstwo krajowe i zobowiązania międzynarodowe. 


\section{PODSUMOWANIE}

Rozwój starań zmierzających do ochrony grzybów w Polsce ma długą historię. Ich ukoronowaniem było włączenie 20 gatunków grzybów wielkoowocnikowych na listę gatunków chronionych w 1983 roku. Ówczesne rozporządzenie było pierwszym aktem prawnym w Europie uwzględniającym grzyby w systemie ochrony gatunkowej ${ }^{48}$. Co prawda porosty objęto ochroną już w 1957 r., jednakże, jak zaznaczono wyżej, długi czas zaliczane były przez systematyków do roślin.

Prawnym narzędziem realizacji ochrony gatunkowej grzybów jest wykaz gatunków zawarty w rozporządzeniu wykonawczym do u.o.p. Obecnie aktem takim jest RozpGrzyby, którego załączniki wymieniają poszczególne kategorie chronionych gatunków.

Pierwsze rozporządzenia (z lat 1957 i 1983) dotyczące ochrony gatunkowej roślin przewidywały jedynie kilkadziesiąt gatunków grzybów. Mimo małej ilości taksonów objętych ochroną, akty te stanowiły krok milowy w ochronie przyrody. Były innowacyjnymi rozwiązaniami prawnymi, chociażby biorąc pod uwagę ówczesne porządki prawne innych krajów europejskich. W 1995 roku ochroną objęto ponad 200 gatunków porostów, natomiast w stosunku do grzybów wielkoowocnikowych wprowadzono ochronę prawie wszystkich znanych gatunków. Następne rozporządzenie z 2001 r. kontynuowało rozwiązania przyjęte wcześniej. Ochronę poszerzono o kolejne gatunki porostów. W okresie tym liczba taksonów podlegających ochronie była największa w dotychczasowej historii. Kolejne rozporządzenie z 2004 r. przyniosło nowe podejście do ochrony gatunkowej grzybów. Po raz pierwszy została ona wyodrębniona z dotychczasowej ochrony roślin. Liczba gatunków chronionych uległa poważnemu ograniczeniu w związku ze zrezygnowaniem z ochrony częściowej w stosunku do grzybów wielkoowoc-

48 A. Kujawa, Ochrona grzybów wielkoowocnikowych w Polsce - stan aktualny, problemy $i$ wyzwania. Głos $w$ dyskusji, „Przegląd Przyrodniczy” 2010, nr 2, s. 42-51. 
nikowych. Za duże osiągnięcie należy uznać z pewnością wprowadzenie stref ochrony stanowisk lub ostoi grzybów. Aktualne rozporządzenie z 2014 r. wpisuje się w trend ograniczania długości list chronionych gatunków. Postępem w dotychczasowych rozwiązaniach legislacyjnych jest $\mathrm{z}$ pewnością zróżnicowanie gatunków na dziko występujące i inne niż dziko występujące.

Poddając analizie jedynie liczbę gatunków włączonych do ochrony prawnej, zauważyć można, że początkowo ona rosła, natomiast po roku 2001 zaczęła być ograniczana. Co ciekawe stopień zagrożenia gatunków rośnie nieprzerwanie od momentu prowadzenia obserwacji przyrodniczych. Obraz postępujących zmian stanowić mogą liczby gatunków porostów zagrożonych umieszczanych w kolejnych wydaniach Czerwonej listy porostów zagrożonych w Polsce. W 1986 roku na liście znajdowało się 480 gatunków o kategorii zagrożenia EX i E (wymarłych i wymierających), w 1992 roku odpowiednio 602, zaś w 2003 r. liczba ta wzrosła do 887 gatunków porostów ${ }^{49}$. Przykład ten obrazuje, że działania prawodawcy polegające na skracaniu wykazów taksonów chronionych nie znajdują uzasadnienia z punktu widzenia stopnia zagrożenia bioróżnorodności. Wśród przyrodników i zwolenników ekologii takie działania prawie zawsze będą budziły sprzeciw.

\section{BIBLIOGRAFIA}

Aktualizacja listy gatunków grzybów objętych ochrona gatunkową oraz wskazania dla ich ochrony, red. A. Kepel, Poznań 2013.

Fałtynowicz W., Porosty $w$ lasach Polski - znaczenie, zagrożenie, ochrona, w: D. Anderwald, Sposoby rozpoznawania, oceny i monitoringu wartości przyrodniczych polskich lasów, Rogów 2006, 4 (14).

Fałtynowicz W., Zagrożenia porostów i problemy ich ochrony, „Przegląd Przyrodniczy" 1997, nr 3.

49 Por. W. Fałtynowicz, Porosty $w$ lasach Polski - znaczenie, zagrożenie, ochrona, w: D. Anderwald, Sposoby rozpoznawania, oceny i monitoringu wartości przyrodniczych polskich lasów, Stud. i Mat. CEPL, Rogów 2006, 4 (14), s. $193-200$. 
Gruszecki K., Ustawa o ochronie przyrody. Komentarz, Warszawa 2013. Jaworowicz-Rudolf A., w: Prawo ochrony różnorodności biologicznej, red. M. Górski, J. Miłkowska-Rębowska, Warszawa 2013.

Jaworowicz-Rudolf A., w: Prawo ochrony środowiska, red. M. Górski, Warszawa 2014.

Kapuściński R., Historia ochrony przyrody w Polsce (1). Ochrona przyrody $w$ Polsce do 1918 roku, „Przyroda Polska” 2013, nr 8.

Kujawa A., Ochrona grzybów wielkoowocnikowych $w$ Polsce - stan aktualny, problemy i wyzwania. Głos $w$ dyskusji, „Przegląd Przyrodniczy" 2010, nr 2.

Latawiec M., Analiza historyczna ustawowych form ochrony przyrody w Polsce, Warszawa 2011.

Radecki W., Zarys historii prawnej ochrony przyrody w Polsce, w: Prawne formy ochrony przyrody, red. J. Sommer, Warszawa 1990.

Symonides E., Ochrona przyrody, Warszawa 2007.

Wierzbowski B., Rakoczy B., Prawo ochrony środowiska. Zagadnienia podstawowe, Warszawa 2012.

Kontakt e-mail:

baxtek@interia.pl 